\title{
Social and economic differentials among households of urban migrants: evidence from Kalutara District, Sri Lanka
}

\author{
Kanthi Manel ${ }^{1 *}$, Sureeporn Punpuing ${ }^{2}$ and Sunethra Perera ${ }^{3}$ \\ ${ }^{I}$ Department of Social Statistics, Faculty of Humanities and Social Sciences, University of Sri Jayewardenepura, Nugegoda, Sri Lanka. \\ ${ }^{2}$ Institute for Population and Social Research, Mahidol University, Thailand. \\ ${ }^{3}$ Department of Demography, Faculty of Arts, University of Colombo, Colombo, Sri Lanka.
}

\begin{abstract}
Migration to urban areas is a common phenomenon in Sri Lanka since more than three decades. Urban population is gradually increased mainly due to various reasons: socioeconomic issues, natural disasters, political and ethnic issues, cultural requirements and improvement in transportation and communication, and migration to urban areas from rural and urban areas. As a result of the migration towards urban areas, socio-economic differences between formal and informal sector households have increased. Therefore, the aim of the study is to explore and estimate the socio-economic differences of household heads of urban migrant households who are engaged in the formal and informal sector economic activities at the destination. Data was obtained quantitatively from a sample survey by using a face-to-face interview technique, covering 400 migrant households from three urban areas in Kalutara District and qualitative information was gathered using indepth interview method. The factors related to social and economic differentials of migrant households were analysed by employing descriptive, bivariate and multivariate analyses.
\end{abstract}

Findings of this study revealed that more than half of migrants belong to the reproductive age group. Three fourths of the household heads among migrants are below secondary level education and parents' aspiration towards the children's education is quite low, especially in the informal sector. Most of the urban migrants' employments are at risk because more than two thirds of migrant household heads are engaged in informal economic activities and more than half of households have no economic security of their urban life. According to the bivariate comparison, formal sector employed households differ significantly from informal sector employed households in terms of respondent's age, resident years at destination, monthly household income, monthly household expenses and Household Assets Index. Furthermore, these differences are enhanced by the multivariate discriminant analysis. Moreover, the qualitative findings discovered that several community and environmental factors such as lack of sanitary facilities and low educational attainment, less awareness and encouragement of employment opportunities have resulted in increasing the negative economic influences within these urban communities.
It is suggested that the future employment programs and awareness programs should directly focus on empowering, especially, informal employees, and new policies should be introduced to reduce the migration towards urban areas and its negative influences on the destination community.

Keywords: Urban migrants, household differentials, formal \& informal households, urban community.

\section{INTRODUCTION}

Migration is a dynamic process and migration towards urban areas is a main component of population movement. Even though rural areas have more resources such as lands for cultivation, natural water facilities, labour force, fresh air and organic food, people often prefer to move from their origin places to urban areas due to various reasons such as lack of financial resources, social resources and facilities which are required to live comfortably at their origin places (Bilsborrow, 2002; Todaro, 1985). In the urban migration process, especially rural to urban migration, a majority of migrants move to urban areas because of the lack of employment opportunities and low actual wages in the rural areas due to economic reasons (Todaro, 1980; Todaro, 1976). Several empirical studies (Herrera \& Shan, 2013; Mahinchai, 2010; Farooq et al., 2005; Caldwell, 1969) also revealed that a large number of people migrate to urban locations due to the relative improvement of different facilities, economic reasons and better living conditions in the urban areas compared to the origin places. The tide of migration to urban areas, which is caused by origin push factors is comparatively higher than the capacity of new employment opportunities, provision of housing and other social services and amenities. The effects of urban ward migration on households and community at the destination are often complex. These movements 
cause differences among urban migrants' households. In developing countries, it is argued that general effects of urban migration on household well-being may not be considerable for several reasons (Okhankhuele, 2013). Most of the migrants are engaged in the urban informal sector economic activities with low wages and gradually try to find jobs in the government sector or private formal sector (Graves \& Linneman, 1979; Todaro, 1985; Tacoli et al., 2015). However, over coming positive influences of urban migration, increase of urbanward migration and urbanisation cause many issues regarding the socioeconomic well-being of migrated households as well as the entire community, and requires timely responses by the planners and policy makers. In this view, urban ward migration should not have been caused to create negative implications as it is also seen to play positive role in socio-economic well-being and development in the urban community. As a result of urbanisation and migration, positive influences such as improvement of urban infrastructure facilities, development of industrial sectors and living facilities can be witnessed. Migrant households can be divided in to formal and informal sector and these two types of households have to face both positive and negative consequences of migration towards urban areas, in developing countries.

In the Sri Lankan context, studies that examined the effect of urban ward migration on household living condition, household well-being at destination, influences of the urban community and differentials among urban migrant livelihoods are inadequate. Available literature on internal migration (Ranathunga, 2011; Ranabahu, 2005; Shayama \& Ranabahu, 2005; Perera \& Ukwatta, 2000) describe rural to urban migration and remittances of left behind rural households, urban migration and poverty alleviation of rural households, reasons for rural to urban migration and so on. Some of them analysed internal migration patterns (De Silva \& Perera, 2005; Perera, 2005; Ukwatta, 2005; Ukwatta, 2000; Abeysekara, 1983). Hence, this study is important as it investigates the differences between formal and informal sector employees who belong to urban migrant households. It also provides information on the possible influences of urban migration on household living condition at the destination.

Therefore, the main objective of this research is to analyse the socio-economic differences between urban migrant households who engage in the formal and informal sector employments. The specific objective of this study is to identify the consequences of migration towards urban areas on the migrants' household living status at destination and the urban community.

\section{AN OVERVIEW OF THE LITERATURE}

Previous studies on internal migration process mainly focused on causes and consequences of before and after migration (Gimba \& Kumshe, 2011; Okhankhuele, 2013; Parveen, 2014; Rokib et al., 2011). Low wage employments and less productivity in the rural informal sector, especially in agricultural sector, mostly influenced the migration of youth from the rural areas. In these studies researchers have tried to identify the socioeconomic factors such as low wages, unemployment issues and lack of social amenities in the origin places that affect migration. According to the findings of the previous studies, migrants would be anticipated to fulfil the objectives which influence migration to urban areas. However, some of them were unable to achieve the objectives at the urban destination due to the negative influences of increasing urban migration and urbanisation issues. Government policies have been formulated in favor of urban development by creating employment opportunities and providing educational opportunities and other infrastructural amenities. More migrants prefer to move to urban areas to engage and utilise modern and technological facilities (Gimba \& Kumshe, 2011; Herrera \& Shan, 2013; Nivalainen, 2004; Okhankhuele, 2013; Parveen, 2014). This has resulted in the inequality in the development and quality of life between rural and urban destination areas, thereby, enhancing migration towards urban areas (Imran et al., 2013; Patnaik et al., 2015).

Some empirical studies highlighted the factors which influence to increase urban migration, such as, easy access to enter to the urban informal sector employments due to and by the prevalence of low wages, inadequate protection of employments and irregularity of employments and earnings in the agricultural sector in the rural areas (Amare et al., 2012; Memon, 2005; Harris, 2003). However, these studies have mainly focused on factors and implications of rural to urban migration but not the differences between migrant households in terms of their livelihoods, employments and social behavior. In most of the developing countries, including Sri Lanka, low income urban migrant families are not satisfied with their household life due to vulnerability in health, education, housing, sanitary facilities and other environmentalissues. Furthermore, some studies have discussed that migration to urban areas has an effect on lowering the productivity of agricultural sector in rural areas (Mazambani, 1990; Rozelle et al., 1999; Todaro, 1976). The agricultural sector has a very large informal labour market in origin areas. Lack of new technology for cultivation, high prices of raw materials and fertilizers have influenced positively to decrease the productivity of agriculture. 
Hence, these studies have highlighted that most of the young people would prefer to engage in urban sector employments. Further, these studies reveal that most of the migrants in urban areas are engaged in informal sector economic activities than formal sector activities.

However, their attempts regarding demonstrating the rural to urban migration are succeeded. Low productivity of agriculture in rural areas and development of urban industrial sector encourage migration of young people to urban areas to seek employment opportunities, more comfortable livelihoods and to utilise other infrastructure facilities and services. Under the theoretical framework of amenities theory, the process of internal migration has been discussed by Khan \& Shehnaz (2000). This study has shown that both males and females migrate due to non-economic reasons. Authors of these studies have found that most of the migrants are engaged in informal economic activities. Even though Khan \& Shehnaz (2000) discussed the necessity of household amenities in the theory of amenities, the satisfaction of urban lives and the difference among migrants' livelihoods and the others have not been discussed.

The study of Imran et al. (2013) found that socioeconomic determinants such as inappropriate educational, health and recreational facilities, poor infrastructure and insufficient economic opportunities are the main factors which affect individual and household level migration to urban areas in Pakistan. Further, this study also concluded that the involuntary migrants have faced economic and social issues at the destinations due to difficulties in engaging in the formal sector employments and linking with the other social networks. They believed that the urban informal labour market structure in developing countries does not accurately show in-migration models but revealed that urban labour market can be divided into two sectors such as high wage formal sector and the low wage informal sector. Further, they explained that most of urban migrant household heads would like to join the informal sector because previous experience is not required and also because of the lack of demand for unskilled human capital by the formal sector.

However, abundant empirical evidence from developing countries has shown the potential negative and positive influences of migration towards urban areas on the destination community. Some researchers (Gimba \& Kumshe, 2011; Okhankhuele, 2013; Meng, 2001) explored that informal sector involuntary migrant workers are living in poor conditions with low income, poor housing and social amenities and unhealthy environment. It also extended that quite a few informal sector migrant workers are there out of choice and have a comfortable life as formal sector workers. According to these studies, they have not concentrated on household level differences but shown the positive effects of urban migration on the urban community. In urban areas, infrastructure facilities, communication facilities and other public services have been improved as a result of increasing urban migration and urbanisation.

Informal sector is the back bone of economic development of developing countries since a large proportion of rural to urban migrants, after moving into the urban areas, join with the informal sector since there are no entry barriers or requirements (Bhattacharya, 1993). However, the studies that discussed the role of informal sector commonly treated the informal sector as an unorganised sector. Further, the informal sector is considered as a pre-capitalist form of production, compared to the formal sector. However, it is a profitable sector that leads to economic development. The available empirical studies show that rural to urban migration influenced to change the household living condition at the origin place since migrated people are engaged in informal sector new employments, getting experiences in the industrial sector and earning more money (Leclere \& McLaughlin, 1997; Shauman \& Noonan, 2007; Todaro, 1985). However, thses studies have not focussed on livelihoods of migrant residents, especially engaging in the informal sector economic activities. When migrating to new locations, people experienced changes in household livelihoods and living environment as well as urban economic development and loses (Farooq, 2006; Ranathunga, 2011; Todaro, 1980). Lewis (1982) and Standing (1984) have highlighted that the urban ward migration is an important part of the economic growth, facilitating industrialisation, improvement of income distribution and innovation of technological changes in the agricultural and non-agricultural sectors. As noted from the previous studies, urban migration has a number of demographic, socio-economic, political and cultural consequences. Many studies have focussed on factors influencing urban migration in the context of the migration of both individual and family level. Few studies that have examined the influences of migration on urban households' social changes, economic background and environmental changes in the urban locations are mainly based on the informal sector employments (Kundu \& Sarangi, 2007; Meng, 2001). These studies have shown different factors of urban ward migration and various implications that influence on both formal and informal sector migrant households and urban livelihoods. Even though, most of the studies on migration focussed on the causes and consequences of rural to urban migration, the studies that examines socio-economic differentials of urban migrant households are inadequate. Moreover, 
studies that compare migrants' household living status and consequences in the formal sector and informal sector employments are limited.

\section{Conceptual Framework}

The effects of urban migration on urban household livelihoods have made more influences regarding the demographic changes, economic changes, environmental changes and changing of household assets. Both origin and destination factors lead to migrate to urban areas and migrants have to face intervening obstacles at the urban areas (Lee, 1966). These obstacles affect to change the migrants' livelihoods engaged in the formal and informal sector in urban communities. Changes of household livelihoods affect urban communities, creating negative and positive influences such as increasing traffic congestions, house congestions, environmental pollution, illegal drug addiction and other social violations, while improved infrastructure facilities, industrial development, better public services, providing good health facilities and more competitive education opportunities, respectively.

\section{METHODOLOGY}

\section{Study area and data collection}

This study is based on primary data collected in three Urban Council (UC) areas (Kalutara, Panadura and Beruwala) of Kalutara District, covering 400 migrant households. A multi stage sampling technique was used to draw the sample for this study. In the first stage, three UC areas from Kalutara District were selected. The selection was based on characteristics such as population density, geographical boundaries etc.. Sample size of each UC area was determined according to the volume of migration and the level of the urbanisation. Next, highly urbanised and highly migrated Grama Niladhari (GN) divisional areas were purposively selected. The selection consisted of four GN divisions from Kalutara UC area (Desastra Western, Mahawatta, Akkaragoda and Welapura), three GN divisions from Panadura UC area (Pattiya South, Wekada Western and Wekada North) and three GN divisions from Beruwala UC area (Kankanamgoda, Massalgoda and Cheenakotuwa). A sample frame of the study was prepared according to

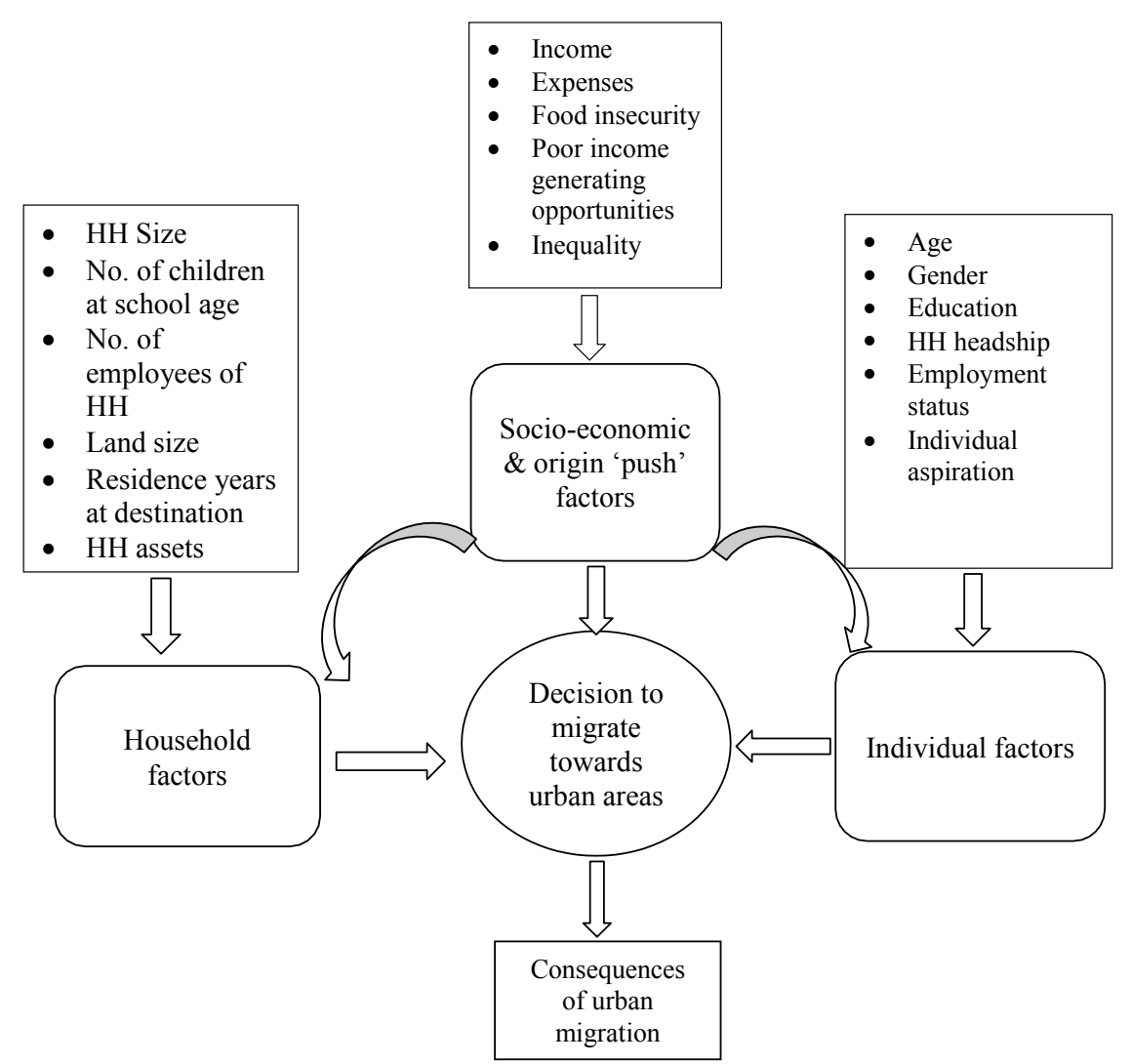

Figure 1: A conceptual framework for the impacts of urban migration on the urban households and the urban communities 
the household lists of each GN division. Finally, from the migrants identified in each GN division, migrant household units were selected by using simple random sampling method covering 40 households from each GN division.

A migrant household was defined as the household, including household head, spouse and children, that move to the urban area from both rural areas and urban areas. Such migrants were identified under four categories: permanent, semi- permanent, voluntary and involuntary migrants. Among migrant families, some of them have migrated to the urban areas to settle down permanently. Some others wanted to re-migrate to another place immediately due to the issues they currently face and they have been identified as semipermanent migrants. In Kalutara and Beruwala urban areas, most of the migrants are involuntary migrants. They do not like to live in the current urban areas because they have to face problems at employment, children's education and facilities, compared with their origin places. Most of them faced the tsunami disaster and shifted to under-development project areas implemented by the government. Rest of the migrants moved to the current residence place since they had to face natural disasters. Encroached people were identified as voluntary migrants because they were satisfied with the destination places. In the study, one household (family) unit was considered as a sample unit. The respondents who live in the selected urban areas confined to at least a nuclear family and migrated to urban locations at least six months prior to the survey date. A four month period was taken for the data collection for this study, from April 2014 to July 2014.

Quantitative data was collected using a questionnaire. It was administered to 400 migrant household heads. Indepth interview method was used to gather qualitative information regarding social and economic differences of migrant households and consequences on the households and the host community. Since data related to 400 migrant households were collected from $10 \mathrm{GN}$ divisions, 10 case studies were examined to represent the household units of each GN division and another 10 case studies were represented as key informants of the Urban Council areas such as Mayor, Reverend, Priest, Urban Council Officer, five Grama Niladari Officers, School Teacher and Public Health Inspector.

\section{Measurements and variables}

The survey has mainly addressed social and economic factors of urban migration and consequences of urban migration on migrant's household. A number of demographic and household factors of migrant families, individual factors and socio-economic factors were included to identify the differences of households living condition. Three major demographic characteristics were included in the analysis to identify the characteristics, which influenced urban migration and the effects on households' livelihoods. The variables are, age and educational level of the household head and household headship ${ }^{2}$. Educational attainment was measured by six different levels in the survey ${ }^{3}$. Household factors consisted with size of the family, number of children at school going age, number of employees of the households, size of the land $\mathrm{l}^{4}$ and residence years at destination. Three variables were included to identify socio-economic factors related to migrant households. Previous research has shown that household income and expenditure are especially difficult to measure. To reduce measurement errors, monthly income and monthly household living expenses were taken as standardised values $^{5}$. In addition, an index variable was included as an indicator of household assets created (Filmer \& Pritchett, 2001) using Principal Component Analysis (PCA) to drive weights for constructing a linear index of a group of asset variables. The asset indicators in this study include; land ownership, ten different household durable consumer goods ${ }^{6}$, extra property ${ }^{7}$ belonging to the household, building materials ${ }^{8}$, number of bed rooms, sanitary facilities ${ }^{9}$, drinking water source ${ }^{10}$ and type of cooking fuel used ${ }^{11}$.

Migrant households were considered as a group variable. Family members who belong to one household unit and migrate from one GN division to another GN division on semi-permanent or permanent, voluntary or involuntary basis is defined as household migration or family migration. Further, if the migrated household head is engaged in formal sector economic activities, household unit of the head is taken as formal sector household and otherwise they belong to informal sector household. Migrant households were divided into two groups such as formal sector and informal sector. In the analysis, variables were selected relevant to the analytical method. All the variables were used for the descriptive analysis and continuous variables were used in the bivariate comparison and multivariate discriminate analysis.

\section{Analytical methods}

The statistical analysis of the study was completed in three phases. First, characteristics of migrants were discribed using descriptive analysis. This statistical method is used to explain variations between different variables: household living status, demographic characteristics 
and socio-economic factors (only continuous variables). Secondly, bivariate analysis was used to identify the significant variables in both household groups. Finally, multivariate discriminant data analysis was employed to compare the differences between household groups in exmainng the effects of migration. This technique is suitable because it allows simultaneous comparison of two or more groups of multiple variables. Further, discriminant analysis was used to classify known and unknown cases with categories.

\section{RESULTS AND DISCUSSION}

The influences of migration towards urban locations on households can be viewed both negatively and positively. Migration affects to increase urbanisation, unemployment issues, income inequalities, ecological issues, housing and traffic congestion and unequal population distribution in urban areas. On the other hand, it affects economically on migrant households and host community by the contribution of economic growth, facilitating industrialisation, improving infrastructure facilitates, improving income distribution and making new technological changes (Standing, 1984). This indicates that urban migration has a number of demographic, socio-economic, political and cultural impacts on migrants and the destination community.

\section{Descriptive analysis of demographic influences of migration on urban locations}

The majority of urban migrants from rural areas are the people in labour-force-age group (15-59 years). Standing (1984) has also pointed out that with the increase in migration to urban areas, population in the labour-forceage group reduces in rural areas. Further, findings of this study also reveals that around two thirds of migrants belong to reproductive age group (20-49 years) ${ }^{12}$. Hence, the population distribution of urban areas may be rejuvenated due to the number of migrants being higher than the original population at destination. According to this, current and the future urban generation would be increased when compared to origin places.

Education is an important demographic characteristic in deciding migration. Male and female migrants with below secondary level education are 75.1 percent and 79.6 percent, respectively. Proportionately, more males with secondary level education and above migrate to urban locations than females. However, the pattern of living of highly educated people who belong to high employment categories and high income groups may lead to traffic congestion and environmental pollution in urban areas because of their commuting patterns. Further, urban migrant parents who engage in informal sector economic activities have less aspiration of the children's education because of their low educational levels.

On the other hand, these families have no sufficient income and therefore, children attain work and earn money as financial support for their families. Several families in urban areas migrated to sub urban areas or foreign countries and sold their lands to businessoriented people. However, most of the children in school going age (63 percent) who live in these urban areas had not completed at least their basic education. Since more migrant families have low education, they tend to work in the informal sector with low facilities and low income than others. Furthermore, results of the study reveal that more than half of families (57 percent) belong to extended family group and live with the least facilities such as small houses and polluted environment. Poor education, less job employment status and low income are the factors which lead the migrants to live in rented houses, slums or shanties. Hence, migrants who engage in the informal sector face number of issues other than non-migrants. Moreover, the entire community suffers from issues due to increasing urban ward migration and urbanisation.

\section{Effects of urban migration on households}

Analysis of the effects of migration on urban living condition was based on information related to the issues faced at destination. Identified issues are, lack of sanitary facilities, inadequacy of housing and extra spaces for children's and elders' activities, inaccessibility of employment opportunities, more competition of formal employments and waste management. According to the responses of migrants employed in the informal sector, their households become crowded than the formal sector households. Among migrant households, 30 percent of families do not own a land or own house because of the insufficiency of income to purchase a land or house which are normally sold at higher prices in urban land areas when compared with rural areas.

Consequently, most migrants have encountered housing and land problems. In this regard, an attempt was made to collect information through in-depth interviews with the relevant officials of the Urban Council areas in the district. It was stated that the urban areas have been facing chronic issues of housing, scarcity of other social facilities and barriers of implementation for other development programs due to increased population. Further, Social Affairs officials of the Urban Council offices revealed that the public money and lands have been allocated to build up resettlement locations for illegal and encroached migrants. Moreover, urban migration increase urban population and unplanned 
urban expansion with insufficient social services such as health, education, sanitary facilities and road expansion to improve the transportation system.

\section{Impact of urban migration on socio-economic status of urban communities}

Migration is mainly focused on economic benefit of both educated and less educated people that migrate to urban areas. According to the household information of this study, lower education level or uneducated and unskilled migrant household heads are engaged in various kind of economic activities, mostly in the informal sector. They are engaged in difficult, messy and hazardous jobs. This study also revealed that most of the migrant household heads (more than 75 percent) are engaged in the informal economic activities. About 24 percent work in sales and demonstrating jobs (shop helpers, salesman, fishery workers), 15.5 percent in handicraft and small producers related to craft works and 37.3 percent are in elementary jobs (cleaning services, child and elderly caring, house cleaning), respectively. However, nearly 21 percent of the respondents with low skills are engaged in daily pay work and they earn low income to sustain their daily lives.

Even though people migrate to urban areas to live and improve their economic background, majority of migrants face economic problems due to several reasons such as high cost of living, employment insecurity issues and health issues. If the household head is not engaged in secured employment, the other family members have to face livelihood issues. More than half of migrant household heads (58 percent) do not have employment security. They had not been contributed to a Provident Fund, pension scheme or other investment as their employment security or future life security. As such, most migrant household heads (approximately 50 percent) have not decided to plan their life security in the future. This is partly because of less educated migrants being often engaged in the informal sector economic activities due to lack of knowledge and money. Rest of the household heads, 35 percent, are maintaining savings accounts in banks. A few respondents who are engaged in the formal sector employment had other investments and joined with an insurance scheme. However, most household heads (71 percent) who are engaged in the formal sector would prefer to join and received benefits of loan schemes to fulfill various purposes of their lives. According to these factors, most migrant families in the sample are at risk in both economic and the security of the future life.

\section{Bivariate comparisons}

Descriptive analysis was conducted to identify the influences of demographic, household characteristics and socio-economic factors of migration on migrant household in the previous section as a preliminary step for the multivariate data analysis. Table 1 shows the mean and range of variables included in the model. Table 2 shows that the bivariate statistical test was done to identify the differences between several demographics, household characteristics, socio-economic factors and household groups. Results of bivariate comparisons of formal sector and informal sector household are shown in Table 2 with statistically significant variables.

Results of the independent T-test shows that household members employed in formal or informal jobs differed significantly by two demographic and household characteristics: household size and number of children at school going age. Generally, migrants who are employed in economic activities in the informal sector have more members in the labour-force-age group than the formal sector migrant households. Migrant households that belong to formal sector are more educated than migrant households in the informal sector employments. The informal sector labour-age migrant household heads' education is low and they have more children below five years of age than the educated migrant families. However, in Sri Lankan context, low income and low educated families who live in urbanised locations have more children due to lack of reproductive healthcare and poor economic background (UNICEF Sri Lanka, 2013).

In addition, these two household groups differed significantly in all socio-economic variables. On average, several household heads who are employed in the formal sector earn a fixed salary per month and most of them do not have other income sources except their primary occupation. Although, their monthly income is less than some informal sector earners, formal sector employments have an employment security. As expected, both these groups of households, on average, are satisfied with their migration life. Nevertheless, several informal sector migrant households enjoyed more with higher expenses for consumption and household assets than formal sector migrants did. However, according to the qualitative information of these informal sector migrants, most of them have no concern on financial management of the household and financial security in the future.

\section{Multivariate discriminant analysis for migrant household groups}

The bivariate analysis suggests that significant differences exist between the formal sector migrant household and the informal sector migrant households in terms of demographic and household characteristics, 
Table 1: Descriptive statistics of variables included in the analysis

\begin{tabular}{|c|c|c|c|c|c|}
\hline Variables & Mean & $\begin{array}{l}\text { Standard } \\
\text { Deviation }\end{array}$ & Minimum & Maximum & Number $(\mathrm{N})$ \\
\hline \multicolumn{6}{|l|}{$\begin{array}{l}\text { Demographic and household } \\
\text { characteristics }\end{array}$} \\
\hline Age of household head & 44.51 & 10.36 & 21 & 59 & 400 \\
\hline Years of residence at destination & 13.28 & 11.21 & 01 & 37 & 400 \\
\hline Household size & 4.63 & 1.71 & 02 & 15 & 400 \\
\hline $\begin{array}{l}\text { Number of employees of the } \\
\text { household }\end{array}$ & 2.60 & 1.06 & 01 & 09 & 400 \\
\hline No. of children at school age & 0.80 & 0.49 & 00 & 03 & 400 \\
\hline \multicolumn{6}{|l|}{ Socio-economic factors } \\
\hline Monthly household income ${ }^{*}$ & $52,49.40$ & $48,7.33$ & 1000.00 & $80,000.00$ & 400 \\
\hline Monthly household expenses* & 2581.90 & 1346.90 & 5193.00 & $105,000.00$ & 400 \\
\hline Household Asset Index ${ }^{* *}$ & 2.22 & 1.00 & 1.20 & 2.40 & 400 \\
\hline
\end{tabular}

Source: Survey data (2015)

Note: All these variables are described in the measurements and variables. In the bivariate and discriminant analysis, monthly household income and expenses were taken as standardized variables to avoid over and under estimation.

${ }^{* *}$ Household assets index was calculated by using Principal Component Analysis (PCA) method.

Table 2: Bivariate comparison of household groups (only migrated households) with T- values

\begin{tabular}{lcc}
\hline Variables & \multicolumn{1}{c}{ Household groups } \\
\cline { 2 - 3 } $\begin{array}{l}\text { Demographic and household } \\
\text { characteristics }\end{array}$ & Employed in formal sector $(\mathrm{HH}=198)$ & Employed in informal sector $(\mathrm{HH}=202)$ \\
Age of household head & 1.436 & 1.448 \\
Years of residence at destination & 1.092 & 1.093 \\
Household size & $1.988^{*}$ & 0.399 \\
Number of employers of the & 0.374 \\
household & $2.451^{*}$ & $2.447^{*}$ \\
Number of children at school age & \\
Socio-economic factors & $3.138^{* *}$ \\
Monthly household income & \\
(standardized) & $2.226^{*}$ \\
Monthly household expenses & \\
(standardized) & $2.666^{* *}$ \\
\hline Household Asset Index & & $3.167^{* *}$ \\
\hline
\end{tabular}

Source: Survey data (2015)

Notes: ${ }^{* *}$ Significant at the 0.01 level; "Significant at 0.05 level

and economic factors. As mantioned earlier, multivariate discriminant analysis was applied to compare migrant households belong to either formal or informal sector employment. In the analysis, two sets of variables were added to build a model to examine the differences between two household groups.

The results of discriminant analysis is shown in Table 3. The model 1 included only demographic and household characteristics of migrants. Household size and children at school age have statistically significant effects in differentiating the two household groups. In model 2, monthly household income, monthly household expenses (standardised values) and Household Assets Index are added into the analysis. Household size and number of children at school age remained statistically significant in distinguishing household groups. The newly added three variables also had a significant effect. In addition, number of employees of the household has significantly affected on household groups. According to these results, the difference between formal and informal sector migratory households is better explained by socio- 
economic variables and household characteristics than demographic characteristics.

This study empirically explored and tested socioeconomic differentials of urban ward migration on households. Bivariate results and the multivariate results show with the exception of effect of several demographic characteristics, household factors and socio-economic factors are statistically significant in differentiating formal and informal sector employees of migrant households. In the discriminant analysis of differences among formal and informal sector households, basically three household characteristics and all socio-economic factors are significantly influenced. Household head's age is not an influencing factor on their employment sector. There is a significant difference between formal sector households and informal sector households with respect to household's monthly living expenses. This is probably due to the fact that these migrants of two household groups live in the same area and should have paid money for every consumption good and service without any categorisation except purchased quantity and brand. Explanation given by one of the migrant household heads in the study is as follows:

"Before we came to this area our cost of living was low and therefore, I could manage my salary to spend for the consumption and other needs. Although now I am getting a higher income than before, it is not enough for our family's food, clothing, medicine and other living conditions. In this area people have more money, more consumption, and on average living expenses are also high" (Household head, age 48, M).
In the bivariate comparisons of two household groups, formal sector migrant households and informal sector migrant households have high monthly living expenditure. Both the bivariate and multivariate discriminant analyses also show that formal and informal sector migrant households expenses do not vary in high rates. The family migration also has a positive impact on their urban households living status. When considering the Household Assets Index, it is statistically significant in both models. In the urban context, living facilities and infrastructure facilities are better than the origin places. It plays a supportive role for better urban lives than the lives at their origin. The following expression supports their argument:

"My wife and I came here before five years. When we came here, we brought our clothes and some money to find a small house. Nevertheless, within this period I built up a new house and completed everything, which are needed for better life. We have all the facilities such as pipe born water, electricity, telephone and electric equipment, and transport, easy access for public services, health facilities and good education for children" (Household head, age 40, M).

According to these explanations, most migrant families in the sample, especially voluntary migrants, were able to improve their urban lives within a short period of time than the involuntary migrants. Involuntary migrant families had to face many issues in the destination settlement as expressed below.

Table 3: Discriminant analysis of differences between migrant households (formal and informal sector), given as $F$ values of variables

\begin{tabular}{lcc}
\hline Variables & Model 1 & Model 2 \\
\hline Demographic and Household characteristics & & 2.060 \\
Age of household head & 2.062 & 1.104 \\
Residence years at destination & 1.194 & $3.400^{*}$ \\
Household size & $3.650^{*}$ & $2.100^{*}$ \\
Number of employees of the household & $2.155^{*}$ & $6.580^{*}$ \\
Number of children at school age & $6.008^{*}$ & \\
Socio-economic factors & & $9.848^{* *}$ \\
Monthly household income (standardized) & & $4.954^{*}$ \\
Monthly household expenses (standardized) & & $7.105^{* *}$ \\
Household Assets Index & &
\end{tabular}

Source: Survey data (2015)

Note: ${ }^{* *}$ Significant at the 0.01 level; ${ }^{*}$ Significant at the 0.05 level 
"In 2004, we faced tsunami disaster and my husband and elder son died. They worked as businessmen in the fishery industry. We had a rich life at our native place. We had four boats and a modern house. Everything was lost. Now I live with my children without a permanent income source except my street vending income. The government has donated this house and house equipment. We do not like to live in this area. It is the most crowded and noisy area. We need to go back to our origin place" (Household head, age $48, \mathrm{~F})$.

There is an improvement in housing facilities, electricity, natural gas, drinking water sources, telephone, television and other house equipment in migrant families as a result of migration.

Although, there is a difference in quality and quantity of the facilities between formal and the informal sector households, after the migration, people had to spend more money to upgrade their living standard. These findings confirm that the influences of urban ward migration on formal sector employees' households and informal sector migrant households are different with respect to household characteristics and socio-economic factors. According to the results of quantitative data, some of qualitative status of households could not be explained quantitatively. However, qualitative information were applied to identify those unexplained areas of formal and informal household conditions. In-depth interviews with the migrants, family members and key informants of the area such as school teachers, reverends of the temple, priest of the church and Grama Niladhari reveal that the voluntary and rich migrant families, who live in the urban communities, do not cause trouble to the households or community. Comparatively, migrants with low level of education and poor economic background have imposed a negative influence on the community as well as their own households due to drug addiction, quarreling, gambling and involving in underworld activities. Findings from the in-depth interviews provide useful information to identify the differentials between household status and explore the implications of urban ward migration on the household living status and the community. One of key informant said:

"Most migrant people in this area had concentrated on the school of children. These families have more children of school going age. Since parents have not secured employments, children dropped out from school without completing their compulsory education. These children join the labour force at younger age and tend to carry out illegal business to earn money. Therefore, parents' aspiration of children's education is more worth to increase our community standard" (GN Officer, age 51, M ).

Semi-permanent migrants do not generate negative impacts on household livelihoods as they rent rooms or upgrade housing condition. In the Kalutara urban area, one of the retired school principal stated as follows:

"I am not a migrant. I live in this area since my birth. Our family members have more lands. They sold these lands and went abroad before 25 years. Within 15 years, many development projects were implemented in this area to provide common facilities such as transport, water, electricity, sanitary, communication and education. Therefore, within a short period, this area has become highly urbanised and commercialised. One of my houses is also rented out for migrant males. My neighbors have given their houses for rent with more confidence. The migrants live in our houses without causing conflicts or disturbances. Generally, most temporary migrants live in a place only for one or two years. Now, origin residencies tend to sell their lands and move to the sub-urban areas due to inconvenience of overcrowding, environmental pollution and other negative influences" (Retired School Principal, age 67, M).

Further, respected people (Priest, Mayor and Reverends) in this area revealed the following common idea about households livelihood, urban population and the host community.

"Land prices are increasing continously. At the beginning, business people who lived in near-by districts like Colombo, Galle, Gampaha came to this area to start businesses and their families come to settle down. Extent of lands became smaller and utilisation of urban common facilities are high. The increasing urban population creates more competitive education system, powerful communication facilities, health facilities and infrastructure facilities as positive influences while environmental pollution, house and traffic congestions and increasing social vulnerabilities and unemployment issues are negative effects on the urban communities. Since this society has multi-ethnic and multi religious groups, more cultural issues are created"(Mayor).

Generally, increasing of urban population influencs to increase the positive and negative consequences on 
the household livelihoods and the well-being of the urban community. Therefore, these influences cause to differ migrant households from each other. This qualitative information provides useful witness to enhance the validity of quantitative findings.

\section{CONCLUSIONS}

This paper is focused on examining the socioeconomic differentials among urban migrant households and consequences of urban migration. It offers an innovative contribution to the literature on family migration through the social and economic behavior of urban family migration in response to reduce positive and negative consequences of migration towards urban areas. Mixed method approach of this study makes it possible to capture differentials of households' livelihoods and influences on the destination community. Previous studies on internal migration had presented the causes and implications of this experience. Literature on family migration towards urban areas in other countries had also focussed on the aspects of determinants and consequences of this phenomenon. This study too observed that there is a reason for family migration and consequences on the households and the destination community. However, in contrast to the literature on local migrations and international level family migrations, data of this study was able to identify the socio-economic differences among urban migrant households. It reveals that urban migrant families who are engaged in informal sector economic activities differ from the formal sector migrant households in terms of living status. Several migrants who settled down in urban setting had improved the household income, quality of life and household consumption style. In other words, the socio-economic status of the migrants at destination is improved. By synthesising the quantitative results with the qualitative findings, it was able to identify the unmatched reasons for migration towards the urban areas. Although, rural to urban and urban to urban migration create both positive and negative consequences on the migrants' livelihoods and the urban society, negative outcomes are more powerful than the positive influences on the urban communities. It is evident that, infrastructure facilities, communication facilities and other social amenities are improved gradually as urbanisation and the migration increased. However, qualitative findings confirmed that the increase in urban migration have influenced to create and increase the negative results on the urban community in the long run. Most families that decided to migrate had involuntary reasons; poorer socio-economic background and cultural and political influences prior to migration. Hence, the flow of migrants to highly urbanised areas from rural or sub-urban areas creates a vast access of labour to the urban labour market and because of this, lower wages as well as issues of accessing employments in the urban areas could occur. In the international context, several studies had identified that socio-economic factors, demographic characteristics and other political issues as reasons for the family migration (Cooke, 2003; Dumon, 1976; Mincer, 1978; Rayn \& Sales, 2011; Root \& Jong, 1991). Previous literature on Sri Lankan migration had not focussed on the urban ward family migration. Hence, this study can be used to obtain knowledge regarding the household level migration and the differences of migrant households. Results of this study suggested that the negative experience of family migration can be made reduced by introducing new programs to improve the infrastructure facilities and develop the human capital of government schools in rural areas. Recently, certain policy makers have identified several urban issues caused by increasing urban population such as traffic congestion, house congestion and unemployment problems. Approximately, 20 percent reported that community and traffic congestion were increased mainly by migration and there is an encroachment of public land near the roads or reservation areas. Key informant interview from Social Affairs officers of the area administration and key personnel of the areas (Priest, Buddhist reverends and teachers) stated that influx of migrants cause not only to overcrowed the urban locations but also influence urban infrastructure and amenities. Migration towards urban areas influences not only the households but also on the destination community. Further, qualitative data revealed that the rate of crime and robberies, illegal drug sales and addiction to illegal substances were increased as the migrants continue to flow towards the urban locations. These undesirable results influence to change the migrant households and the urban livelihoods. However, in many ways, urban migration influence on urban households as well as the destination society. Action has been taken to provide basic solutions for those issues through the urban development programs but much remains to be done. Furthermore, these attempts can be made successful by ensuring that decentralising public services and facilities to the sub-urban and the rural areas and introducing small industries in rural areas.

\section{ACKNOWLEDGEMENT}

Authors would like to thank the University of Colombo for providing research grant $(\mathrm{AP} / 3 / 2012 / \mathrm{CG} / 07)$ to undertake this research.

\section{END NOTES}

1. Age of household head is in between 21 and 59 years.

2. Household head may be male or female. 
3. Educational levels are; never being to school, grade five and below grade five, secondary level school education (grade 6-10), passed GCE Ordinary Level and grade 12, passed GCE Advance Level and diploma, degree and above level education.

4. If the household has its own land, the extent of it (perches).

5. Data related to monthly household income and expenses converted to standardized values to avoid the over and under estimation.

6. These durable consumer goods include; motorcar, van, motor bicycle, foot bicycle, trios, radio, television, computer, landline telephone, mobile phone and other durable goods.

7. Extra property includes extra land, extra house.

8. Building materials contain roof materials, floor materials and wall materials.

9. Sanitation facilities mean type of toilets facilities.

10. Water source includes own tap water supply, well, tube well, common tap.

11. Cooking fuel includes traditional fuel materials and modern materials.

12. Although, the reproductive age is $15-49$ years, in this study 20-49 years considered as reproductive age group. Because of respondents who were selected family migrants. All household heads are married and ages are more than 20 years.

\section{REFERENCES}

Abeysekara, D. (1983) Rural to rural migration in Sri Lanka, In C. Goldscheider (Ed.) Rural Migration in Developing Nation: Comparative studies of Korea, Sri Lanka and Mali, US: Westview Press.

Amare, M., Hohfeld, L., Jitsuchon, S. and Waibel, H. (2012) Rural-urban migration and employment quality: A case study from Thailand, ADB Economics Working Paper Series No. 309, Manila: Asian Development Bank.

Arif, G. and Hamid, S. (2009) Urbanization, city growth and quality of life in Pakistan, European Journal of Social Sciences, 10(2), pp: 196-215.

Bilsborrow, R. E. (2002) Migration, population change, and the rural environment, Environmental Change and Security Project Report, 8(1), pp: 69-84.
Caldwell, J. (1969) African rural-urban migration: The movement to Ghana's towns, Canberra: Australian National University Press.

Cooke, T. (2003) Family migration and the relative earnings of husbands and wives, Annals of the Association of American Geographers, 93(2), pp: 338-349.

DOI: https://doi.org/10.1111/1467-8306.9302005

De Silva, W. and Perera, S. (2005) Determinants and trends of migration in Sri Lanka, 1981- 2001, Economic Review, 33, pp: 4-9.

Dumon, R. (1976) Family migration and family reunion, International Migration, 14(1-2), pp: 53- 83.

DOI: https://doi.org/10.1111/j.1468-2435.1976.tb00408.x

Farooq, M. (2006) Consequences of internal migration on family institution in Punjab: A case study in Faisalabad (Pakistan), Journal of Agriculture \& Social Sciences, 2(2), pp: 75-78.

Farooq, M., Mateen, A. and Cheema, M. (2005) Determinants of migration in Punjab, Pakistan: A case study of Faisalabad Metropolitan, Journal of Agriculture \& Social Sciences, 1(3), pp: 280-282.

Filmer, D. and Pritchett, H. (2001) Estimating wealth effects without expenditure data or tears: an application to educational enrollments in states of an India, Demography, 38(1), pp: 115132.

Gimba, Z. and Kumshe, M. (2011) Causes and effects of ruralurban migration in Borno State: A case study of Migduguri Metropolis, Asian Journal of Business and Management Sciences, 1(1), pp: 168-172.

Graves, P. and Linneman, P. (1979) Household migration: Theoretical and empirical results, Urban Economics, 6, pp: 383-404.

DOI: https://doi.org/10.1016/0094-1190(79)90038-X

Harris, N. (2003) Migration of labour -Constructing transnational arrangements, Economic and Political Weekly, 38(42), pp: 18-24.

Herrera, C. and Shan, D. (2013) Determinants of internal migration among Senegalese youth, Ithaca, NY: Dyson School of Applied Economics and Management, Cornell University.

Imran, F., Nawaz, Y., Farooq, M. and Hashmi, A. (2013) SocioEconomic Determinants of Rural Migrants in Urban Setting: A Study Conducted at City Sargodha, Pakistan, Academic Journal of Interdisciplinary Studies, 2(1), pp: 71-76.

DOI: https://doi.org/10.5901/ajis.2013.v2n1p71

Khan, A. and Shehnaz, L. (2000) Determinants of international migration in Pakistan: Evidence from the labour force survey 
1996-97, The Pakistan Development Review, 39(4), pp: 695712.

Kuhn, R. (2005) The Determinants of Family and Individual Migration: A Case Study of Rural Bangladesh, Working paper presented at the Research Program on Population Processes POP2005-05, Institute of Behavioral Science, pp: 1-40.

Kundu, A and Sarangi, N. (2007) Migration, employment status and poverty- An analysis across urban centers, Economic and Political Weekly, 42(4), pp: 299-306.

Leclere, F. and McLaughlin, D. (1997) Family Migration and Changes in Women's Earnings: A Decomposition Analysis, Population Research and Policy Review, 16(4), pp: 315-335. DOI: https://doi.org/10.1023/A:1005781706454

Lee, E. (1966) A Theory of Migration, Demography, 3(1), pp: 47-57.

DOI: https://doi.org/10.2307/2060063

Lewis, G. (1982) Human migration: A geographical perspectives, New York: St Martin's Press.

Lewis, W. A. (1954) Economic Development with Unlimited Supplies of Labor, The Manchester School, 22(2), pp: 139-191. DOI: https://doi.org/10.1111/j.1467-9957.1954.tb00021.x

Mahinchai, M. (2010) Determinants of migration: A case study of Nang Rong, Thailand, North Carolina: Trinity College of Duke University [Online] Available from: econ. duke.edu/uploads/assets/Undergraduate/Past $\% 20$ Honors $\% 20$ Theses/Mahinchai_ho nor_thesis_revised.pdf [Accessed: $7^{\text {th }}$ November 2016].

Mazambani, D. (1990) Labour migration influences communal land agriculture: Case studies from Manical and Province, Zimbabwe, Doctoral Dissertation, Worcester: Clark University. Memon, R. (2005) Determinants and Trends of Internal Migration in Pakistan, In Hisaya Oda (ed.) Internal Labour Migration in Pakistan, Chiba, Japan: Institute of Developing Economies, Japan External Trade Organization.

Meng, X. (2001) The informal sector and rural-urban migrationA Chinese case study, Asian Economic Journal, 15(1), pp: 71-89.

DOI: https://doi.org/10.1111/1467-8381.00124

Mincer, J. (1978) Family migration decisions, Journal of Political Economy, 86(5), pp: 749- 773.

DOI: https://doi.org/10.1086/260710

Mincer, J. (1977) Family Migration Decisions, New York: Center for Economic Analysis of Human Behavior and Social Institutions, National Bureau of Economic Research.

Misra, P. and Alam, M. (2014) Urban informal sector and migrants, International Journal of Business and Administration Research Review, 2(4), pp: 72-86.
Nivalainen, S. (2004) Determinants of Family Migration: Short Moves vs. Long Moves, Journal of Population Economics, 17(1), pp: 157-175.

DOI: https://doi.org/10.1007/s00148-003-0131-8

Okhankhuele, O. (2013) Causes and consequences of ruralurban migration Nigeria: A Case study of Ogun Waterside local government area of Ogun State, Nigeria, British Journal of Arts and Social Sciences, 16(1), pp: 185-194.

Parveen, S. (2014) Causes of Women Labour and Earnings in Urban Informal Sector: A Case Study of Aligarh City, International Journal of Interdisciplinary and Multidisciplinary Studies, 2(1), pp: 52-61.

Patnaik, M., Satpathy, I., Mohanty, J. and Mandal, A. (2015) Determinants of migration from rural to urban India by the labourer- An overview, Journal of Business Management and Social Sciences Research (JBM\&SSR), 4(1), pp: 33-38.

Perera, S. (2005) Patterns, determinants and consequences of internal migration in Sri Lanka 1981-2001, IWE Journal, 5, pp: 76-101, Colombo: Institute of Workers' Education.

Perera, S. and Ukwatta, S. (2000) Demography of Sri Lanka, Issues and Challenges, Colombo, Sri Lanka: Department of Demography, University of Colombo.

Ranabahu, P. (2005) Demographic characteristics of urban in-migrants in the Gampaha District, Sri Lanka Journal of Population Studies, 8.

Ranathunga, S. (2011) Impact of rural to urban labour migration and remittances on sending household welfare: a Sri Lanka case study, Working paper - 35943. [Online] Available from: http://mpra.ub.uni-muenchen.de/35943/ [Accessed: $7^{\text {th }}$ November 2016].

Ravenstein, E. (1885) The laws of migration, Journal of the Statistical Society of London, 48(2), pp: 167-235.

DOI: https://doi.org/10.2307/2979181

Rayn, L. and Sales, R. (2011) Family Migration: The Role of Children and Education in Family Decision-Making Strategies of Polish Migrants in London, International Migration, 51(2).

Rokib, A., Alam, R. and Goni, A. (2011) Influencing factors of socio-economic and demographic characteristics on female migrants' study of Meherpur Sadar Thana, Bangladesh, The Social Sciences, 6(3), pp: 194-197.

DOI: https://doi.org/10.3923/sscience.2011.194.197

Root, B. and Jong, G. (1991) Family migration in a developing country, Population Studies, 45(2), pp: 221-233.

DOI: https://doi.org/10.1080/0032472031000145406

Rozelle, S., Taylor, E. and Brauw, A. (1999) Migration, remittances and agricultural productivity in China, The 
American Economic Review, 89(2), pp: 287-291.

DOI: https://doi.org/10.1257/aer.89.2.287

Shauman, K. and Noonan, M. (2007) Family migration and labour force outcomes: Sex differences in occupational context, Social Forces, 85(4).

DOI: https://doi.org/10.1353/sof.2007.0079

Shayama, R. and Ranabahu, P. (2005) Demographic characteristics of Urban in-Migrants in Gampaha District, Sri Lanka Journal of Population Studies, 8, pp: 45- 64.

Sjaastad, L. A. (1962) The costs and returns of human migration, Journal of political Economy, 70(5, Part 2), pp: 80-93.

DOI: https://doi.org/10.1086/258726

Standing, G. (1984) Population mobility and productive relations: demographic links and policy evolution, Washinton, D.C: World Bank.

Styczyńska, I. (n.d.) Determinants of household demand for services- formal versus informal sector, CASE Reports, Warszawa, Poland: Center for Social and Economic Research.

Tacoli, C., McGranahan, G. and Satterthwaite, D. (2015) Urbanization, rural- urban migration and urban poverty, Working Paper, International Institute for Environment and Development. [Online] Available from: http://pubs.iied.org/ pdfs/10725IIED.pdf [Accessed: $7^{\text {th }}$ November 2016].
Todaro, M. (1980) Internal migration in developing countries: A survey, In R. A. Easterlin (ed.) Population and Economic Change in Developing Countries, pp: 361-402, Chicago: University of Chicago Press. [Online] Available from: http:// www.nber.org/chapters/c9668.pdf [Accessed: $7^{\text {th }}$ November 2016].

Todaro, M. (1985) Economic development in the third world, pp: 247-284, New York and London: Longman.

Todaro, M. (1976) Migration and economic development: A Review of theory, evidences, methodology priorities, Nairobi Institute of Development Study, University of Nairobi.

Todaro, M. (1969) A model of labour migration and urban unemployment in less developed countries, The American Economic Review, 59, pp: 138-149.

Ukwatta, S. (2000) Migration and urbanization in Sri Lanka: An overview, Sri Lanka Journal of Population Studies, 3, pp: $67-84$.

Ukwatta, S. (2005) Internal migration of women and development in Sri Lanka, In Workshop Background Paper, pp: 1-13, Lanzhou, China: People's Republic of China Ministry of Foreign Affairs

UNICEF Sri Lanka (2013) Out of schoolchildren in Sri Lanka: Country study (All children in school by 2015), pp: 1-140, Colombo: UNICEF. 